\title{
PALLADIUM AND RUTHENIUM DERIVATIVES STABILISED BY BIS-SULFONE LIGAND
}

\author{
NOÉMI DEAK ${ }^{a, b}$, RALUCA SEPTELEAN ${ }^{a}$, IONUT-TUDOR MORARU a, \\ SONIA MALLET-LADEIRA ${ }^{c}$, DAVID MADEC ${ }^{b *}$, GABRIELA NEMES $^{a *}$
}

\begin{abstract}
The synthesis and characterization of new palladium and ruthenium derivatives using the bis-sulfone 1,3-bis\{(4-methylphenyl)sulfonyl $\}$ 5 -tert-butylbenzene ligand is presented. The new compounds were characterized in solution by multinuclear NMR spectroscopy and for the palladium derivative the molecular structure in solid state was also determined by single crystal X-ray diffraction. The work was completed with a DFT study in order to better understand the electronic effect in the stabilization of the new complexes containing bis-sulfone ligand.
\end{abstract}

Keywords: bis-sulfone, palladium and ruthenium derivatives, NBO analysis

\section{INTRODUCTION}

Inorganic and organometallic chemistry developed significantly in the last period, mainly due to the possibility to control the properties of designed compounds by using versatile ligands with modulated structures connected to the central atom.

Structural modifications of the ligand backbone and its functional groups allowed access to a large number of compounds whose properties change depending on the connection mode to the metal atom.[1-4] Additionally, the metallic center plays also an important role in the properties of the new compounds; this fact must to be considered at the design of new species. It is well known that organometallic derivatives containing a transition metal

\footnotetext{
a Universitatea Babeş-Bolyai, Facultatea de Chimie şi Inginerie Chimică, str. Arany Janos, nr. 11, RO-400028, Cluj-Napoca, Romania.

b Université de Toulouse, UPS, LHFA, 118 Route de Narbonne, F-31062 Toulouse, France, CNRS, LHFA, UMR 5069, F-31062 Toulouse Cedex 9, France.

c Institut de Chimie de Toulouse, FR2599, Université Paul Sabatier, UPS, 118 Route de Narbonne, F-31062 Toulouse Cedex 9, France.

* Corresponding authors: sgabi@chem.ubbcluj.ro, madec@chimie.ups-tlse.fr
} 
are used mainly in various catalytic processes[5,6] as compounds with biological activity[7-10] or used as building blocks for obtaining of inorganic polymers or supramolecular structures,[6,11-14] these important applications being the reason for significant developments of this field of chemistry in the last period. There are numerous examples of palladium and ruthenium complexes obtained with different ligands whose coordination modes determine not only the stability of the species but also the chemical properties they display. Among the large variety of ligands used for these complexes are for example different phosphines,[15] sulfoxides,[16] Schiff bases[17] or pincer ligands.[13,14,18-20]

Furthermore, the preparation of ligands with properties modulated by the presence of several functional groups like: metallylenes,[21-23] oxathia- derivatives,[24] germil-aminophosphoric esters,[25] phophaalkenyl derivatives[26-28] or organometallic halogenated derivatives[29-31] as well as their study for the stabilization of transition metals derivatives of palladium, ruthenium, gold, tungsten, etc., is a continuous concern in our team.

Recently, we highlighted the utility of the bis-sulfone ligand 1,3-bis\{(4methylphenyl)sulfonyl\}-5-tert-butylbenzene, containing two sulfonyl groups, as a pincer ligand for the stabilization of metallylenes and their transition metal compounds and cycloadducts.[32,33] In order to evaluate the properties and stability of organometallic derivatives containing a heavy $p$-block element or transition metal, additionally the effect induced by a ligand containing sulfonyl groups was studied. It's worth mentioning that in the literature there are several examples for transition metal containing derivatives stabilized by sulphur based, sulfonyl or sulfinyl containing ligands, where the transition metal is bonded either through the coordination of the sulphur or the oxygen atom,[16,34-37] however, there are only a few examples for such compounds containing a bis-sulfonyl ligand.[37]

Herein, we present the results obtained with the before mentioned bissulfone ligand in the synthesis of new palladium and ruthenium derivatives.

\section{RESULTS AND DISCUSSIONS}

The 1,3-bis\{(4-methylphenyl)sulfonyl\}-5-tert-butylbenzene ligand, hereafter named bis-sulfone 1, was synthetized according to the previously described procedure.[32] For this study, compound 1 was tested to obtain transition metal complexes with the aim to further investigate the connection ability of 1 towards transition metals. The synthetic pathway to obtain the palladium and ruthenium derivative is shown in Scheme 1. 
In the case of both palladium 2 and ruthenium 3 derivatives, the ${ }^{1} \mathrm{H}$ NMR spectra indicate the formation of the new compounds by the disappearance of the signal for the $\mathrm{H} 1$ proton from bis-sulfone 1 (Scheme 1) at $8.90 \mathrm{ppm}$. The signals for the ortho protons of the tolyl groups are downfield shifted to $8.55 \mathrm{ppm}$ for palladium complex 2 and to $8.61 \mathrm{ppm}$ for ruthenium complex $\mathbf{3}$ from $7.82 \mathrm{ppm}$ in bis-sulfone $\mathbf{1}$, while an upfield shift can be observed for the signals corresponding the meta protons $\mathrm{H} 3$ and $\mathrm{H} 5$ of the central aromatic ring to $8.06 \mathrm{ppm}$ for palladium complex 2 and 7.32 ppm for ruthenium complex 3 from $8.25 \mathrm{ppm}$ in bis-sulfone 1 . For the palladium complex 2 in the ${ }^{1} \mathrm{H}$ NMR spectrum signals at $2.48,2.81 \mathrm{ppm}$ and $5.44,6.38 \mathrm{ppm}$ can be seen, suggesting that the cyclooctadiene is still linked to the metal center. In the case of the ruthenium complex $\mathbf{3}$, the signals at $6.87-7.03,7.84,7.55 \mathrm{ppm}$ corresponding to 30 protons indicate the presence of two triphenylphosphine groups bonded to the ruthenium atom.

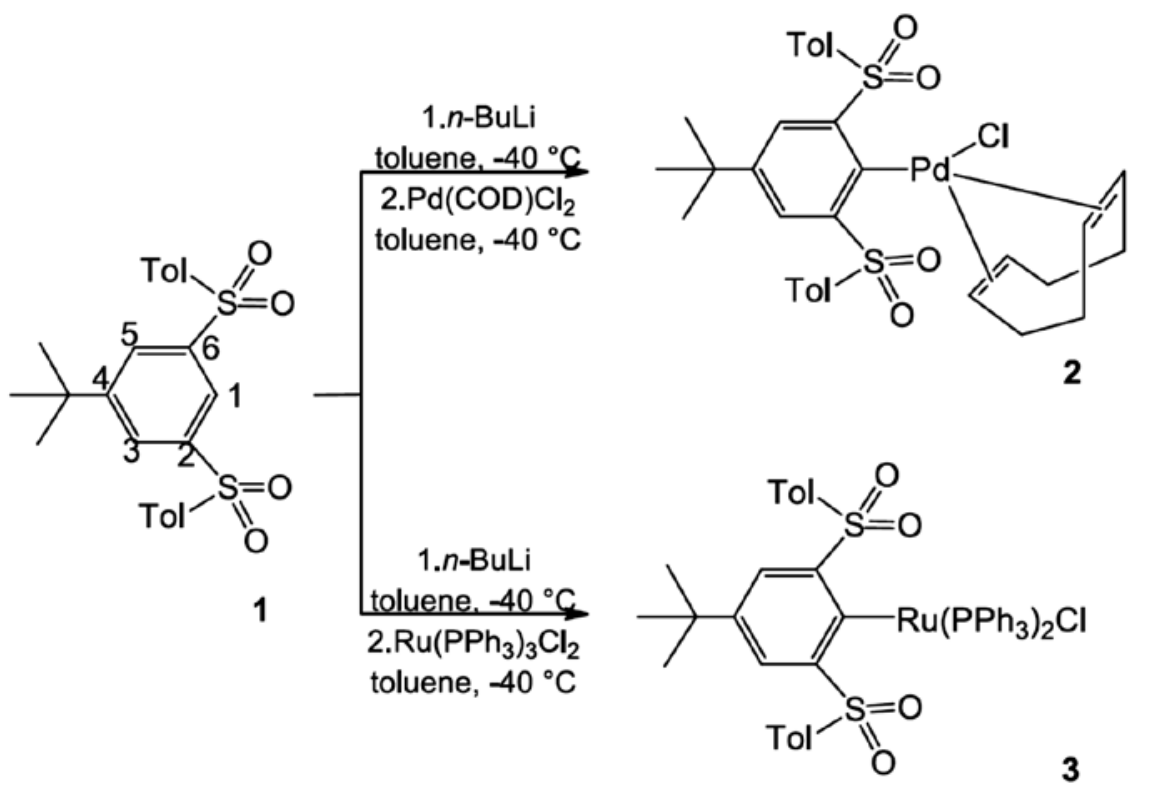

Scheme 1. Synthesis of palladium complex 2 and ruthenium complex 3

The ${ }^{31} \mathrm{P}\{\mathrm{H}\}$ NMR of the ruthenium derivative 3 presents two doublet signals at $52.3 \mathrm{ppm}\left({ }^{2} \mathrm{~J}_{P-P}=23.39 \mathrm{~Hz}\right)$ and $25.4 \mathrm{ppm}\left(\mathrm{d},{ }^{2} \mathrm{~J}_{P-P}=23.45 \mathrm{~Hz}\right)$, also confirming that two triphenylphosphine groups are linked to the metal. The ${ }^{13} \mathrm{C}$ NMR data for both derivatives $\mathbf{2}$ and $\mathbf{3}$ support these observations. All the NMR data are presented in the experimental part. 
Crystals of palladium complex 2 were obtained by diffusion of pentane in dichloromethane solution and were analyzed by single crystal Xray diffraction; the solid state molecular structure of compound $\mathbf{2}$ is shown in Figure 1.

The solid state molecular structure confirms the formation of the complex, where the palladium atom is linked to the $\mathrm{C} 1$ carbon atom of the bis-sulfone ligand. It also confirms the structure deduced from the ${ }^{1} \mathrm{H}$ and ${ }^{13} \mathrm{C}$ NMR spectra, that not only a chlorine atom is linked to the palladium atom, but also the cyclooctadiene group remains coordinated.

The palladium atom is four coordinated, with the usual square planar geometry. The geometrical features are in agreement with values from the literature for other palladium complexes with similar ligands.[13,14,19,20] The tolyl groups are situated on the same side of the central aromatic ring, not on opposite sides, as seen in the case of the previously reported metallylenes, as a consequence of the steric hindrance of the cyclooctadiene group. This effect was also observed in the previously reported transition metal complexes of the metallylenes.[32]

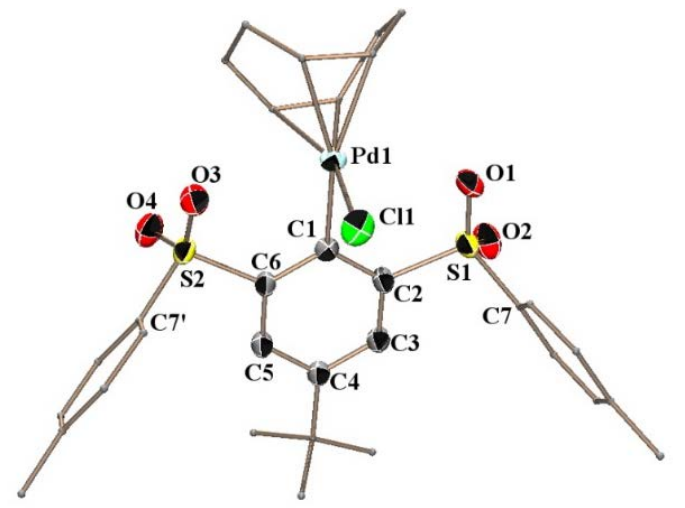

Figure 1. Molecular structure of compound 2 the solid state (50\% probability level for the thermal ellipsoids). For clarity, hydrogen atoms are omitted, tolyl and t-butyl and cyclooctadiene groups are simplified. Selected bond distances $[\AA]$ and bond angles [deg]: S1-O1 1.433(4), S1-O2 1.450(4), S2-O3 1.440(3), S2-O4 1.422(4), Pd1-C1 2.004(5), Pd1-Cl1 2.343(2), C1-Pd1-Cl1 86.04(14), C2-S1-C7 105.7(2), C6-S2-C7' 106.1(2), Pd1-C1-C2 122.7(3), Pd1-C1-C6 122.1(3)

The distance O1-Pd1 is 2.803(4) $\AA$, while O3-Pd1 is 2.806(3) $\AA$, values almost equal and significantly larger than the sum of the covalent radii of the $\mathrm{Pd}$ and $\mathrm{O}$ atoms (2.05).[38-40] The C1-Pd1, S1-O1, S2-O3 bonds are situated roughly in the same plane with the central aromatic ring (S1-O1 $0.074 \AA$, S2-O3 $0.277 \AA$ out of the plane), arrangement favorable for interaction between the oxygen and palladium atoms. However, interaction 
cannot be possible because of the presence of the cyclooctadiene group, thus in this case the bis-sulfone ligand $\mathbf{1}$ does not function as a pincer ligand as in the case of the previously reported metallylenes and their transition metal derivatives.

Furthermore, the oxygen atoms being a hard donor while the palladium atom a soft one, also effects the formation a coordinative bond. However, in the literature, a few examples can be found where an oxygen atom coordinates to a palladium atom.[20] The molecular structure of palladium compound 2 was additionally analyzed through DFT calculations. The calculated lengths of selected Pd-C (2.023 $\AA$ ), $\mathrm{Pd}-\mathrm{Cl}(2.353 \AA)$ chemical bonds are in agreement with the solid-state data, as well as the Pd-O distances $(2.855 \AA$ and 2.867 $\AA)$. For the two $\eta^{2}(C=C) \rightarrow P d$ coordinative bonds, the distances between the palladium atom and the centroids of the $\mathrm{C}=\mathrm{C}$ bonds, have calculated values of $2.179 \AA$ for the one oriented in trans with respect to the $\mathrm{Pd}-\mathrm{Cl}$ bond, and of $2.290 \AA$ for the other one. These lengths indicate strong interactions between the palladium atom and cyclooctadiene group.

NBO calculations, carried-out on the optimized structure of species 2 , revealed also strong $\eta^{2}(C=C) \rightarrow P d$ interactions. According to these calculations, the energy corresponding to the short $(\mathrm{C}=\mathrm{C}) \rightarrow \mathrm{Pd}$ coordinative bond (with calculated length of $2.179 \AA$ ) was computed to be around $78 \mathrm{kcal} / \mathrm{mol}$, with about $64.1 \mathrm{kcal} / \mathrm{mol}$ corresponding to the $\pi(\mathrm{C}=\mathrm{C}) \rightarrow \mathrm{Pd}$ interactions and 13.9 $\mathrm{kcal} / \mathrm{mol}$ to the $\sigma(\mathrm{C}-\mathrm{C}) \rightarrow \mathrm{Pd}$ ones; the NB orbitals involved within these donoracceptor interactions are illustrated in Figure 2. For the other $(\mathrm{C}=\mathrm{C}) \rightarrow \mathrm{Pd}$ chemical bonding, NBO data revealed an interaction energy of about 49.5 $\mathrm{kcal} / \mathrm{mol}$, with $11.9 \mathrm{kcal} / \mathrm{mol}$ arising from $\sigma(\mathrm{C}-\mathrm{C}) \rightarrow \mathrm{Pd}$, and the rest up to the total amount from the $\pi(\mathrm{C}=\mathrm{C}) \rightarrow \mathrm{Pd}$ electron departures.

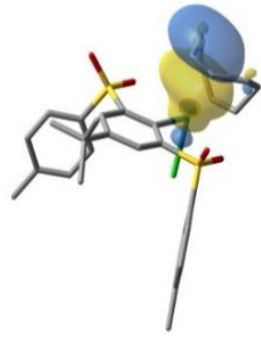

a

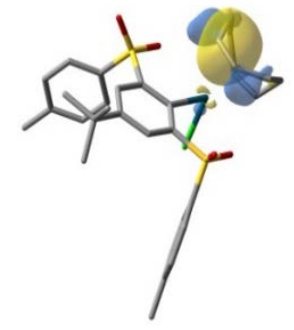

b

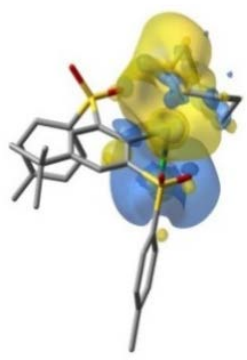

C

Figure 2. NB orbitals involved in the charge transfer interactions of the type $\eta^{2}(C=C) \rightarrow P d$ for one of the two coordinative bonds; a) $\pi(C=C)$ donor component on

cyclooctadienyl species; b) $\sigma(\mathrm{C}-\mathrm{C})$ donor component on cyclooctadienyl species;

c) acceptor orbital situated on the palladium atom; $\mathrm{H}$ atoms were omitted for clarity. NBOs with similar shapes were obtained for the other $\eta^{2}(C=C) \rightarrow P d$ chemical bonding. 
A potential chemical reaction involving palladium derivative 2 (see Figure 3) could be of interest due to the formation of a chelated O,C,Ocoordinating pincer-type $\mathrm{Pd}$ complex, 2_a. DFT calculations, performed on species 2_a, indicate $\mathrm{Pd}-\mathrm{O}$ bond lengths of $2.173 \AA$ and $2.176 \AA$. According to NBO analyses, the calculated energies corresponding to these $\mathrm{O} \rightarrow \mathrm{Pd}$ chemical bondings is around $78 \mathrm{kcal} / \mathrm{mol}$ for each contact $(77.4 \mathrm{kcal} / \mathrm{mol}$ and $78.1 \mathrm{kcal} / \mathrm{mol}$, respectively).
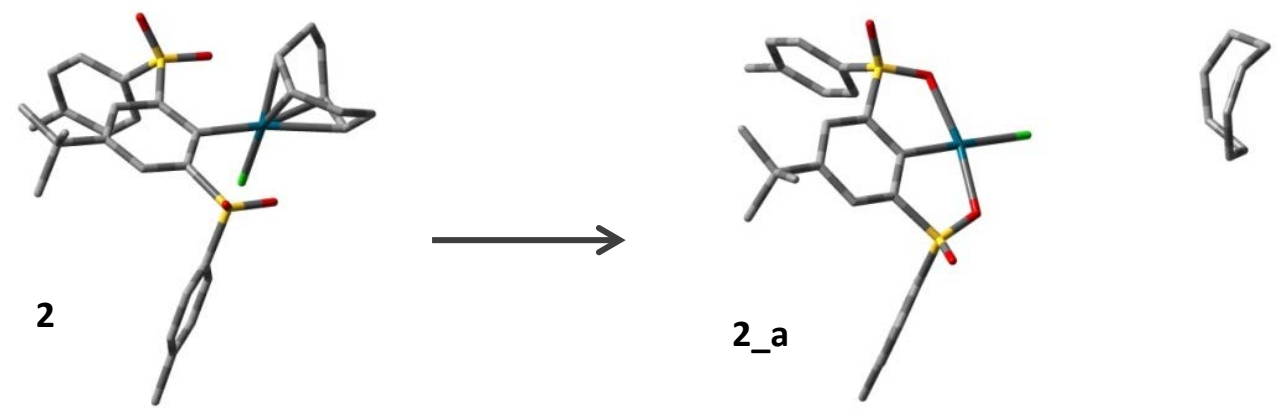

Figure 3. Potential chemical decomposition of complex $\mathbf{2}$ into a pincer-type palladium complex, 2_a, and the cyclooctadiene group; hydrogen atoms were omitted for clarity.

The total energy corresponding to the $\mathrm{O} \rightarrow \mathrm{Pd}$ interactions in complex 2_a $(155.5 \mathrm{kcal} / \mathrm{mol})$ is with $28 \mathrm{kcal} / \mathrm{mol}$ higher than the one calculated for the $\eta^{2}(C=C) \rightarrow P d$ ones within derivative $2(127.5 \mathrm{kcal} / \mathrm{mol})$. According to the calculated energies of the investigated species, the reaction presented in Figure 3 is not thermodynamically favorable. Thus, the calculated energy of complex $\mathbf{2}$ is with $38.8 \mathrm{kcal} / \mathrm{mol}$ lower than the sum of the computed energies of 2 a and of the free cyclooctadiene group (zero-point energy - ZPE corrections were included in all cases). However, this energy difference could be significantly overestimated due to possible basis set superposition error.

The ruthenium complex $\mathbf{3}$ was also investigated by using DFT analysis. The optimized structure of $\mathbf{3}$ indicates a quasi-octahedral arrangement around the ruthenium atom with strong Ru-P bonds with calculated lengths of $2.393 \AA$, for the Ru-bond displaced in trans with respect to the Ru-C chemical bonding, and $2.261 \AA$ for the one placed in the cis position. Short bond length was also calculated for the Ru-C bond (2.005 $\AA$ ) while the Ru$\mathrm{Cl}$ one has a calculated length of around $2.533 \AA$. For the Ru-O contacts, distances of 2.212 - $2.214 \AA$ were obtained. 


\section{CONCLUSIONS}

New palladium and ruthenium complexes were obtained using a bissulfone ligand. Both complexes, 2 and 3, were characterized by NMR spectroscopy in solution and complex 2 also by single crystal X-ray analysis. It was shown that the bis-sulfone ligand $\mathbf{1}$ is also suitable to obtain transition metal derivatives; these compounds are the first examples of complexes with this ligand, opening the road to a new class of derivatives supported by sulfone based ligands. NBO analysis brought further explanations to the formation of the obtained palladium derivative. Furthermore, DFT calculations also supported the formation of the ruthenium complex

\section{EXPERIMENTAL PART}

All manipulations were realized in a dry, oxygen-free argon atmosphere using Schlenk-line and glove-box techniques. All the solvents were purified with a MBRAUN SBS-800 apparatus. The NMR spectra were recorded with a Bruker Avance II 300 apparatus: ${ }^{1} \mathrm{H}(300.13 \mathrm{MHz}),{ }^{13} \mathrm{C}(75.48 \mathrm{MHz}),{ }^{31} \mathrm{P}(121.51 \mathrm{MHz}$, reference $\mathrm{H}_{3} \mathrm{PO}_{4}$ ) at $298 \mathrm{~K}$. High-resolution mass spectrometry (HRMS) spectra were measured with a GCT Premier Waters in DCI mode $\left(\mathrm{CH}_{4}\right)$. The X-ray data were collected at 193(2) K on a Bruker - AXS APEX II Quazar diffractometer, equipped with a $30 \mathrm{~W}$ air-cooled microfocus source using $\mathrm{MoK}_{\alpha}$ radiation (wavelength $=0.71073 \AA$ ). Phi- and omega- scans were used. The data were integrated with SAINT[41] and an empirical absorption correction with SADABS[42] was applied. The structures were solved by direct methods using SHELXS-97[43] and refined using a least-squares method on $F^{2}$. All non- $\mathrm{H}$ atoms were refined with anisotropic displacement parameters. CCDC 1829298 (2) contains the supplementary crystallographic data for this paper. These data can be obtained free of charge from The Cambridge Crystallographic Data Centre via uww.ccdc.cam.ac.uk/data_request/cif

Computational Chemistry calculations were performed within the Density Functional Theory (DFT) framework. The hybrid functional used was B3LYP[44,45] in conjunction with Grimme's D3 dispersion correction,[46] along with the triple-zeta Def2-TZVP basis set[47] and Stuttgart effective core potentials[47] for the relativistic core electrons of the $\mathrm{Pd}$ atom. Optimization criteria were set to tight, vibrational analysis being performed on the optimized structures. The integration grid used was of 99 radial shells and 950 angular points for each shell $(99,950)$. All the calculations were carried out using the Gaussian 09 package.[48] Natural Bond Orbital (NBO)[49-51] single-point calculations were performed using the Gaussian implemented version of the NBO Program.[52] 
Synthesis of (2,6-(para-tolylsulfonyl)-4-tert-butylphenyl)-palladium- $\eta^{2}$ cyclooctadienyl chloride 2

To a solution of bis-sulfone 1 (150 $\mathrm{mg}, 0.34 \mathrm{mmol})$ in $6 \mathrm{~mL}$ toluene cooled to $-40^{\circ} \mathrm{C}, n$-butyl lithium $(0.22 \mathrm{~mL}, 0.36 \mathrm{mmol}, 1.6 \mathrm{M}$ in hexane) was added dropwise. The deep red solution was stirred 20 minutes at this temperature then was added over a suspension of $\mathrm{Cl}_{2} \mathrm{Pd}(\mathrm{COD})(97 \mathrm{mg}, 0.34 \mathrm{mmol})$ in 2 $\mathrm{mL}$ toluene at $-40^{\circ} \mathrm{C}$. The dark red reaction mixture was stirred for 15 minutes at this temperature then allowed to warm slowly to room temperature and stirred for 18 hours, to become a black solution. After the evaporation of the volatiles, the compound was washed with $\mathrm{Et}_{2} \mathrm{O}$ and obtained as a dark grey powder. (135 mg, yield $=58 \%$ ) Colourless crystals suitable for $\mathrm{X}$-ray analysis were obtained by slow diffusion of pentane in $\mathrm{CH}_{2} \mathrm{Cl}_{2}$ solution.

${ }^{1} \mathrm{H}$ NMR $\left(\mathrm{CDCl}_{3}\right) \delta=1.05(\mathrm{~s}, 9 \mathrm{H}, t-B u), 2.37(\mathrm{~s}, 6 \mathrm{H}, \mathrm{Me}), 2.95$ and $3.12(\mathrm{~m}$, $\left.\mathrm{CH}_{2} \mathrm{COD}\right) 5.54\left(\mathrm{~m}, 2 \mathrm{H}, \mathrm{CH}\right.$ COD), $6.34\left(\mathrm{~m}, 2 \mathrm{H}, \mathrm{CH}\right.$ COD), $7.26\left(\mathrm{~d}, 4 \mathrm{H},{ }^{3} \mathrm{~J}_{\mathrm{HH}}\right.$ $=7.98 \mathrm{~Hz}, m-\mathrm{CH} \mathrm{Tol}), 7.56(\mathrm{~s}, 2 \mathrm{H}, m-\mathrm{CH} \mathrm{Ph}), 8.08\left(\mathrm{~d}, 4 \mathrm{H},{ }^{3} \mathrm{~J}_{\mathrm{HH}}=8.30 \mathrm{~Hz}, \mathrm{O}-\right.$ $\mathrm{CH}$ Tol).

${ }^{1} \mathbf{H} \operatorname{NMR}\left(\mathbf{C}_{6} \mathbf{D}_{6}\right) \delta=0.86(\mathrm{~s}, 9 \mathrm{H}, t-B u), 1.73(\mathrm{~s}, 6 \mathrm{H}, \mathrm{Me}), 2.48$ and $2.81(\mathrm{~m}$, $\left.\mathrm{CH}_{2} \mathrm{COD}\right) 5.44$ (m, 2H, CH COD), 6.38 (m, 2H, CH COD), 6.75 (d, $4 \mathrm{H},{ }^{3} \mathrm{~J}_{\mathrm{HH}}$ $=7.96 \mathrm{~Hz}, m-\mathrm{CH} \mathrm{Tol}), 8.06(\mathrm{~s}, 2 \mathrm{H}, m-\mathrm{CH} \mathrm{Ph}), 8.55\left(\mathrm{~d}, 4 \mathrm{H},{ }^{3} \mathrm{~J}_{\mathrm{HH}}=8.28 \mathrm{~Hz}, \mathrm{O}-\right.$ $\mathrm{CH}$ Tol).

${ }^{13} \mathrm{C}$ NMR $\left(\mathrm{C}_{6} \mathrm{D}_{6}\right) \delta=21.8(\mathrm{Me}), 30.8(t-\mathrm{Bu}), 34.4(\mathrm{C} t-\mathrm{Bu}), 28.2$ and $31.3\left(\mathrm{CH}_{2}\right.$ COD), 107.4 and 122.4 (CH COD), 128.8 (o-CH Tol), 129.8 (C3, C5), 131.8 (m-CH Tol), 139.0, 140.4, 144.1, 147.7, 149.7.

HR-MS (DCl CH$):\left(\mathrm{C}_{32} \mathrm{H}_{37} \mathrm{O}_{4} \mathrm{~S}_{2} \mathrm{PdCl}\right)$ [M-Cl] ${ }^{+}$calcd: 655.1179, found: 655.1182 .

Synthesis of (2,6-(para-tolylsulfonyl)-4-tert-butylphenyl)-rutheniumbis(triphenyphosphine) chloride 3

To a solution of bis-sulfone 1 (150 $\mathrm{mg}, 0.34 \mathrm{mmol})$ in $6 \mathrm{~mL}$ toluene cooled to $-40^{\circ} \mathrm{C}, n$-butyl lithium $(0.22 \mathrm{~mL}, 0.36 \mathrm{mmol}, 1.6 \mathrm{M}$ in hexane) was added dropwise. The deep red solution was stirred 20 minutes at this temperature then was added over a suspension of $\left(\mathrm{PPh}_{3}\right)_{3} \mathrm{RuCl}_{2}(325 \mathrm{mg}, 0.34 \mathrm{mmol})$ in $1 \mathrm{~mL}$ toluene at $-40^{\circ} \mathrm{C}$. The dark red solution was allowed to warm slowly to room temperature and stirred for 18 hours. After the evaporation of the volatiles, the compound was washed with $\mathrm{Et}_{2} \mathrm{O}$ and pentane to obtain it as a light brown powder. (110 $\mathrm{mg}$, yield $=30 \%)$.

${ }^{1} \mathbf{H} \operatorname{NMR}\left(\mathbf{C}_{6} \mathbf{D}_{6}\right) \delta=0.85(\mathrm{~s}, 9 \mathrm{H}, t-B u), 1.77(\mathrm{~s}, 6 \mathrm{H}, \mathrm{Me}), 6.71\left(\mathrm{~d}, 4 \mathrm{H},{ }^{3} \mathrm{~J}_{\mathrm{HH}}=\right.$ $8.09 \mathrm{~Hz}, m-\mathrm{CH}$ Tol$), 6.87-7.03\left(\mathrm{~m}, \mathrm{PPh}_{3}\right), 7.32(\mathrm{~d}, 2 \mathrm{H}, \mathrm{J}=1.37 \mathrm{~Hz}, m-\mathrm{CH}$ $\mathrm{Ph}), 7.55\left(\mathrm{~m}, \mathrm{PPh}_{3}\right), 7.85\left(\mathrm{~m}, \mathrm{PPh}_{3}\right), 8.61\left(\mathrm{~d}, 4 \mathrm{H},{ }^{3} \mathrm{~J}_{\mathrm{HH}}=8.38 \mathrm{~Hz}, \mathrm{O}-\mathrm{CH} \mathrm{Tol}\right)$. ${ }^{13} \mathrm{C}$ NMR $\left(\mathrm{C}_{6} \mathrm{D}_{6}\right) \delta=21.2(\mathrm{Me}), 31.1(t-\mathrm{Bu}), 34.5(\mathrm{C} t-\mathrm{Bu}), 130.5$ (C8, C12), 127.1 (d, J = 2.28 Hz, C3, C5), 129.8 (C9, C11), 144.7 (C7), 145.8 (C2, C6), 
136.8, (C10), 148.3 (d, J = $1.87 \mathrm{~Hz}, \mathrm{C} 4), 186.7$ (dd, $\mathrm{J}=10.09$ and $76.09 \mathrm{~Hz}$, C1), 127.3, 127.4, 127.6, 127.8, $129.6\left(\mathrm{PPh}_{3}\right), 134.2\left(\mathrm{~d},{ }^{3} \mathrm{~J}_{P C}=9.33 \mathrm{~Hz}\right.$, $\left.\mathrm{PPh}_{3}\right), 135.4,135.7\left(\mathrm{PPh}_{3}\right), 135.5\left(\mathrm{~d},{ }^{3} \mathrm{~J}_{P C}=10.99 \mathrm{~Hz}, \mathrm{o}, \mathrm{m}-\mathrm{CH} \mathrm{PPh}_{3}\right), 136.2$ $\left(\mathrm{d},{ }^{3} \mathrm{~J}_{P C}=10.82 \mathrm{~Hz}, o, m-\mathrm{CH} \mathrm{PPh}_{3}\right), 138.3\left(\mathrm{~d},{ }^{1} \mathrm{~J}_{P C}=28.11 \mathrm{~Hz}\right.$, ipso-PPh ${ }_{3}$.

${ }^{31} \mathrm{P}$ NMR $\left(\mathrm{C}_{6} \mathrm{D}_{6}\right) \delta=52.3(\mathrm{~m}), 25.4(\mathrm{~m})$

${ }^{31} \mathrm{P}\{\mathrm{H}\}\left(\mathrm{C}_{6} \mathrm{D}_{6}\right) \delta=52.3\left(\mathrm{~d},{ }^{2} \mathrm{~J}_{P-P}=23.39 \mathrm{~Hz}\right), 25.4\left(\mathrm{~d},{ }^{2} \mathrm{~J}_{P-P}=23.45 \mathrm{~Hz}\right)$

IR (nujol) $\vee\left(\mathrm{cm}^{-1}\right)=1595,1465,1377,1321,1261,1187,1146,1106,1058$, $1009,814,741,695,662,586,520$

\section{ACKNOWLEDGEMENTS}

This work was supported by a grant of Ministery of Research and Innovation, CNCS - UEFISCDI, project number PN-III-P4-ID-PCE-20160351, within PNCDI III, by the Babeș-Bolyai University of Cluj-Napoca and by the Centre National de la Recherche Scientifique (CNRS) and the Université de Toulouse (UPS).

\section{REFERENCES}

1. N. Fey, A.G. Orpen and J. N. Harvey, Coorination Chemistry Reviews, 2009, 253, 704.

2. J.R. Khusnutdinova and D. Milstein, Angewandte Chemie International Edition, 2015, 54, 12236.

3. C. Gunanathan and D. Milstein, Accounts of Chemical Research, 2011, 44, 588.

4. G. van Koten, Pure and Applied Chemistry, 1989, 61, 1681.

5. E. Negishi, Ed., Handbook of Organopalladium Chemistry for Organic Synthesis, John Wiley \& Sons, Inc., New York, USA, 2002.

6. D. Morales-Morales and C. Jensen, Eds., The Chemistry of Pincer Compounds, Elsevier, 2007.

7. P. Jia, R. Ouyang, P. Cao, X. Tong, X. Zhou, T. Lei, Y. Zhao, N. Guo, H. Chang, Y. Miao and S. Zhou, Journal of Coordination Chemistry, 2017, 70, 2175.

8. U. Schatzschneider, European Journal of Inorganic Chemistry, 2010, 2010, 1451.

9. M.Á. Martínez, M.P. Carranza, A. Massaguer, L. Santos, J.A. Organero, C. Aliende, R. de Llorens, I. Ng-Choi, L. Feliu, M. Planas, A.M. Rodríguez, B.R. Manzano, G. Espino and F.A. Jalón, Inorganic Chemstry, 2017, 56, 13679.

10. Y. Zhang, Q. Zhou, N. Tian, C. Li and X. Wang, Inorganic Chemstry, 2017, 56, 1865.

11. M. Albrecht and G. van Koten, Angewandte Chemie International Edition, 2001, 40, 3750. 
12. E. Holder, B.M.W. Langeveld and U.S. Schubert, Advanced Materials, 2005, 17, 1109.

13. G. Van Koten and R.A. Gossage, The Privileged Pincer-Metal Platform: Coordination Chemistry \& Applications, Springer International Publishing, Cham, 2016, vol. 54.

14. G. van Koten and D. Milstein, Eds., Organometallic Pincer Chemistry, Springer Berlin Heidelberg, Berlin, Heidelberg, 2013, vol. 40.

15. D. Zhang and Q. Wang, Coorination Chemistry Reviews, 2015, 286, 1.

16. G. Sipos, E.E. Drinkel and R. Dorta, Chemical Society Reviews, 2015, 44, 3834.

17. P. Das and W. Linert, Coorination Chemistry Reviews, 2016, 311, 1.

18. H.P. Dijkstra, M.Q. Slagt, A. McDonald, C.A. Kruithof, R. Kreiter, A.M. Mills, M. Lutz, A.L. Spek, W. Klopper, G.P.M. van Klink and G. van Koten, European Journal of Inorganic Chemistry, 2003, 2003, 830.

19. J. Vicente, A. Arcas, M.-A. Blasco, J. Lozano and M.C. Ramírez de Arellano, Organometallics, 1998, 17, 5374.

20. G.R. Fulmer, W. Kaminsky, R.A. Kemp and K.I. Goldberg, Organometallics, 2011, 30, 1627.

21. R. Septelean, I.-T. Moraru, T.-G. Kocsor, N. Deak, N. Saffon-Merceron, A. Castel and G. Nemes, Inorganica Chimica Acta, 2018, 475, 112.

22. D. Matioszek, T.-G. Kocsor, A. Castel, G. Nemes, J. Escudié and N. Saffon, Chemical Communication, 2012, 48, 3629.

23. T.-G. Kocsor, G. Nemes, N. Saffon, S. Mallet-Ladeira, D. Madec, A. Castel and J. Escudié, Dalton Transactions, 2014, 43, 2718.

24. G. Carel, D. Madec, A. Saponar, N. Saffon, G. Nemes, G. Rima and A. Castel, Journal of Organometalic Chemistry, 2014, 755, 72.

25. S. Ech-Cherif El Kettani, J. Escudié, C. Couret, H. Ranaivonjatovo, M. Lazraq, M. Soufiaoui, H. Gornitzka and G. Cretiu Nemes, Chemical Communication, 2003, 1, 1662.

26. R. Septelean, G. Nemes, J. Escudié, I. Silaghi-Dumitrescu, H. Ranaivonjatovo, P. Petrar, H. Gornitzka, L. Silaghi-Dumitrescu and N. Saffon, European Journal of Inorganic Chemistry, 2009, 2009, 628.

27. R. Septelean, H. Ranaivonjatovo, G. Nemes, J. Escudié, I. Silaghi-Dumitrescu, H. Gornitzka, L. Silaghi-Dumitrescu and S. Massou, European Journal of Inorganic Chemistry, 2006, 2006, 4237.

28. P.M. Petrar, R. Şeptelean, N. Deak, H. Gornitzka and G. Nemeş, Journal of Organometalic Chemistry, 2015, 787, 14.

29. L. Baiget, M. Bouslikhane, J. Escudie, G.C. Nemes, I. Silaghi-Dumitrescu and L. Silaghi-Dumitrescu, Phosphorus Sulfur Silicon and Related Elements, 2003, 178, 1949.

30. G.C. Nemes, L. Silaghi-Dumitrescu, I. Silaghi-Dumitrescu, J. Escudié, H. Ranaivonjatovo, K.C. Molloy, M.F. Mahon and J. Zukerman-Schpector, Organometallics, 2005, 24, 1134.

31. G. Nemes, J. Escudié, I. Silaghi-Dumitrescu, H. Ranaivonjatovo, L. SilaghiDumitrescu and H. Gornitzka, Organometallics, 2007, 26, 5136.

32. N. Deak, P.M. Petrar, S. Mallet-Ladeira, L. Silaghi-Dumitrescu, G. Nemeş and D. Madec, Chemistry - a European Journal, 2016, 22, 1349. 
33. N. Deak, I.-T. Moraru, N. Saffon-Merceron, D. Madec and G. Nemes, European Journal of Inorganic Chemistry, 2017, 2017, 4214.

34. J. Becker and V.H. Gessner, Organometallics, 2014, 33, 1310.

35. D. Madec, F. Mingoia, C. Macovei, G. Maitro, G. Giambastiani and G. Poli, European Journal of Organic Chemistry, 2005, 2005, 552.

36. A. Szadkowska, K. Żukowska, A.E. Pazio, K. Woźniak, R. Kadyrov and K. Grela, Organometallics, 2011, 30, 1130.

37. T. Tuntulani, G. Musie, J.H. Reibenspies and M.Y. Darensbourg, Inorganic Chemistry, 1995, 34, 6279.

38. B. Cordero, V. Gómez, A.E. Platero-Prats, M. Revés, J. Echeverría, E. Cremades, F. Barragán and S. Alvarez, Dalton Transactions, 2008, 2832.

39. M. Mantina, A.C. Chamberlin, R. Valero, C.J. Cramer and D.G. Truhlar, Journal of Physical Chemistry A, 2009, 113, 5806.

40. A. Bondi, Journal of Physical Chemistry, 1964, 68, 441.

41. SAINT, Program for data reduction, Bruker-AXS.

42. SADABS, Program for data correction, Bruker-AXS.

43. SHELXS-97, SHELXL-14 Program for Crystal Structure refinement, G.M. Sheldrick, Acta Crystallographica Section A 2008, 64, 112. SHELXL, G.M. Sheldrick, Acta Crystallographica Section C, 2015, 71, 3.

44. C. Lee, W. Yang, R.G. Parr. Physical Review B, Condensed Matter and Materials Physics, 1988, 37, 785.

45. A.D. Becke. Journal of Chemical Physics, 1993, 98, 5648.

46. S. Grimme, J. Antony, S. Ehrlich, H. Krieg. Journal of Chemical Physics, 2010, 132, 154104.

47. D. Rappoport, F. Furche. Journal of Chemical Physics, 2010, 133, 134105.

48. M.J. Frisch, G.W. Trucks, H.B. Schlegel, G.E. Scuseria, M.A. Robb, J.R. Cheeseman, G. Scalmani, V. Barone, G.A. Petersson, H. Nakatsuji, X. Li, M. Caricato, A. Marenich, J. Bloino, B.G. Janesko, R. Gomperts, B. Mennucci, H.P. Hratchian, J.V. Ortiz, A.F. Izmaylov, J.L. Sonnenberg, D. Williams-Young, F. Ding, F. Lipparini, F. Egidi, J. Goings, B. Peng, A. Petrone, T. Henderson, D. Ranasinghe, V.G. Zakrzewski, J. Gao, N. Rega, G. Zheng, W. Liang, M. Hada, M. Ehara, K. Toyota, R. Fukuda, J. Hasegawa, M. Ishida, T. Nakajima, Y. Honda, O. Kitao, H. Nakai, T. Vreven, K. Throssell, J.A. Montgomery, Jr., J.E. Peralta, F. Ogliaro, M. Bearpark, J.J. Heyd, E. Brothers, K.N. Kudin, V.N. Staroverov, T. Keith, R. Kobayashi, J. Normand, K. Raghavachari, A. Rendell, J.C. Burant, S.S. lyengar, J. Tomasi, M. Cossi, J.M. Millam, M. Klene, C. Adamo, R. Cammi, J.W. Ochterski, R.L. Martin, K. Morokuma, O. Farkas, J.B. Foresman, D.J. Fox, Gaussian 09, revision E.01; Gaussian, Inc.: Wallingford, CT, 2009.

49. F. Weinhold, C.R. Landis, Valency and Bonding: A Natural Bond Orbital DonorAcceptor Perspective; Cambridge Univ. Press: Cambridge, U.K., 2005.

50. F. Weinhold, C.R. Landis, Discovering Chemistry with Natural Bond Orbitals; Wiley-Interscience: Hoboken, NJ., 2012.

51. F. Weinhold, C.R. Landis, E.G. Glendening, International Reviews in Physical Chemistry, 2016, 35, 399.

52. E.D. Glendening, A.E. Reed, J.E. Carpenter, F. Weinhold, NBO Version 3.1. 